
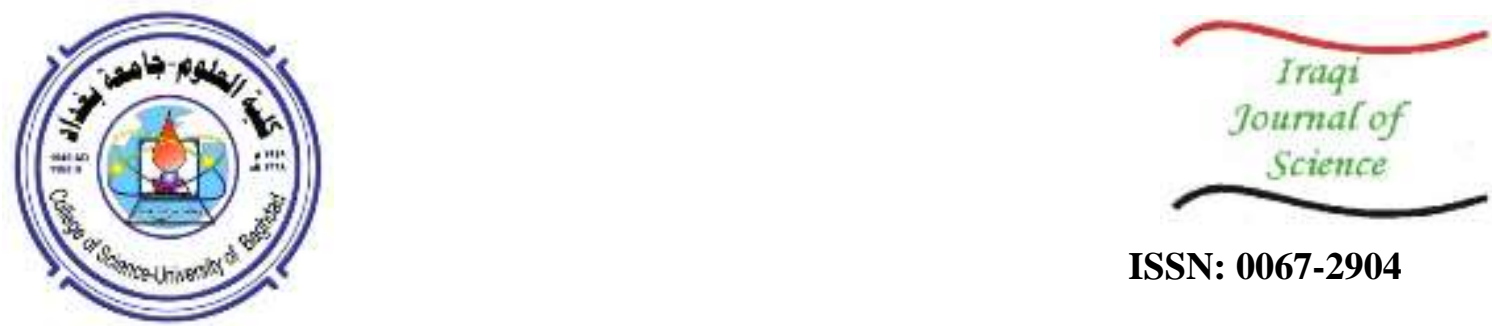

ISSN: 0067-2904

\title{
Efficiency of Plant Active Compounds as Anti-Adhesion Factors for Clinical Candida albicans Isolates in vitro
}

\author{
Majid Rasheed Majeed *, Dhuha Hussein Khairallah \\ Department of Biotechnology, College of Science, University of Baghdad, Baghdad, Iraq
}

Received: 18/11/2019 Accepted: 31/12/2019

\begin{abstract}
The aim of this study is the determination of the anti-adhesion activity of active compounds extracted from plants in the inhibition of adhesion ability of C. albicans that is used as a virulence factor for infection. Adherence to host surfaces is a primary factor in the colonization of human tissues by fungi, which can also adhere to the surfaces of medical devices and form biofilms. Medicinal plants possess therapeutic properties or beneficial pharmacological effects on the body. A total of one hundred samples were collected from female patients with vaginal infection in two hospitals in Baghdad city for three months. The fungi were isolated and identified by microscopic morphology, morphological features on culture media, and Vital Index of Traditional Environmental Knowledge (VITEK 2) System. Extraction and purification of plant active compounds, vasicine from Adhatoda vasica and gallic acid from Punica granatum $L$. , were performed. The active compounds were used as anti-adhesion factors and the minimum inhibition concentration (MIC) against Candida albicans was determined. We also used the antifungal drug fluconazole for comparison as a control. The results of vaginal discharge characterization of clinical samples showed that $30 \%$ of the infections are caused by fungi ( $100 \%$ were Candida albicans), $47 \%$ by Gram negative bacteria, and $23 \%$ by Gram positive bacteria. The results of MIC assays showed that the plant extract and the antifungal drug do not seem to have fungicidal effects on the isolates of $C$. albicans tested. The ability of $C$. albicans isolates for adhesion to the epithelial cells was detected by the calculation of the number of adherent $C$. albicans cells under light microscope. The activity of vasicin and gallic acid appeared to be approximately equal on the number of $C$. albicans adherent on epithelial cells. Vasicin concentration activity used in $\mathrm{mg} / \mathrm{ml}$ was higher than that used in $\mu \mathrm{g} / \mathrm{ml}$, with less numbers of $C$. albicans adhered on epithelial cell. However, treatment with fluconazole showed that more than half of the number of $C$. albicans were nonadherent on epithelial cells when added to the suspension, in contrast to the control (C. albicans without the extracts or antifungal drug).
\end{abstract}

Keywords: Efficiency: Candida albicans: Vasicine: Gallic acid; anti-adhesions.

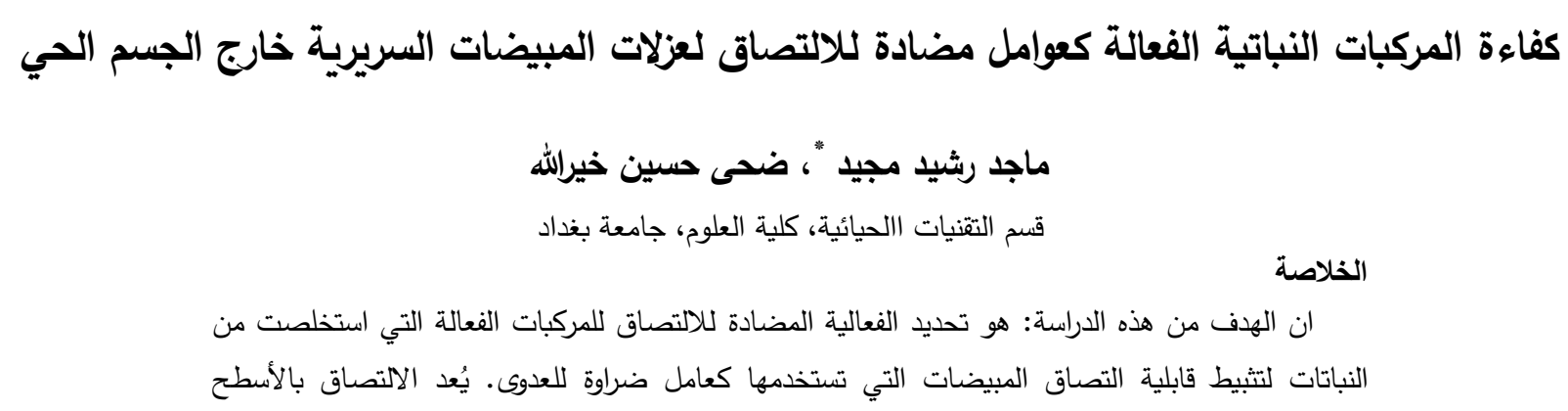

*Email: msalewandy@yahoo.com 


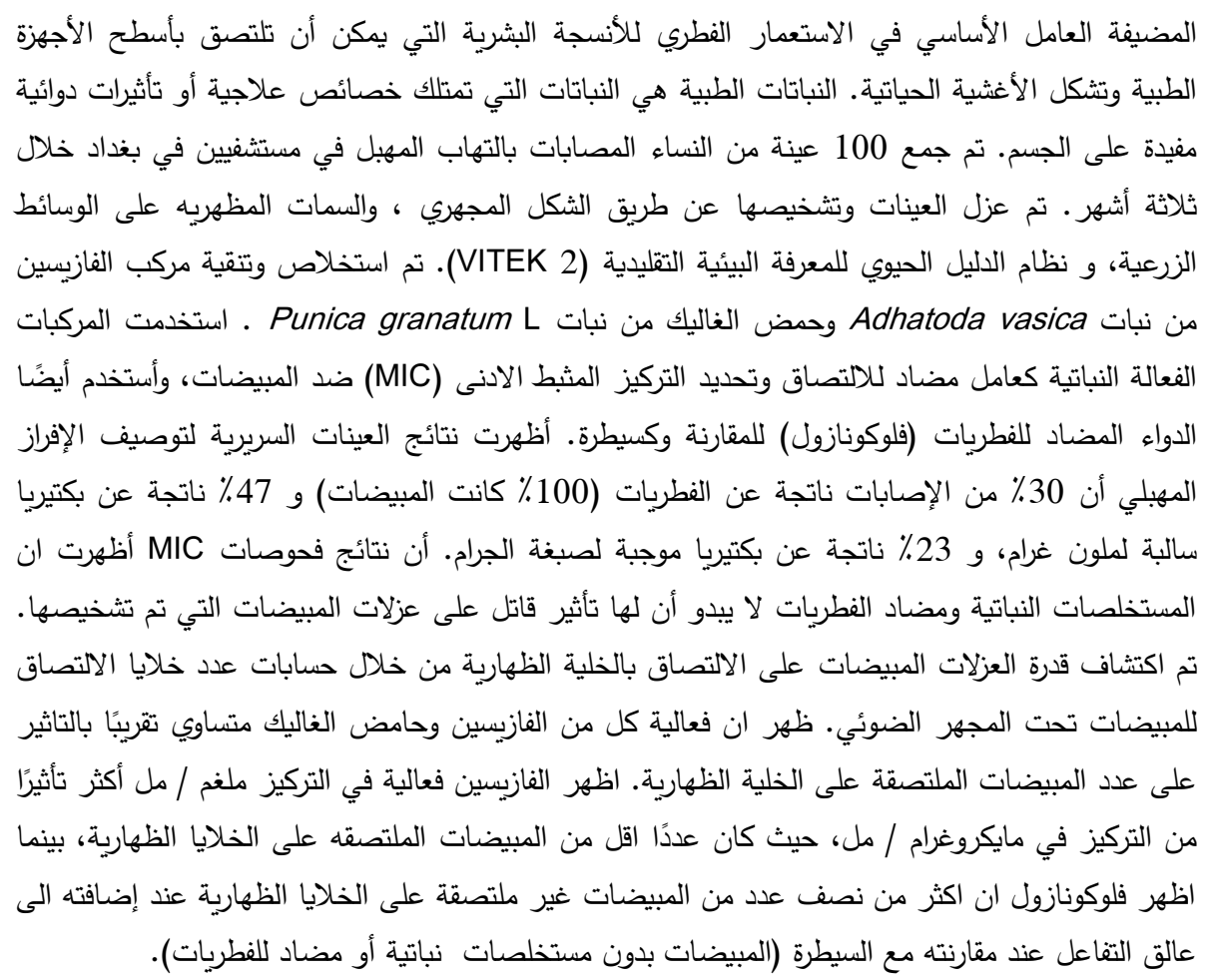

\section{Introduction}

Candida infection is the main cause of nosocomial bloodstream infections (BSIs) in tertiary care hospitals worldwide. These organisms are the most common cause of superficial vaginal or mucosal oral infections and may under propitious conditions enter the bloodstream leading to deep-tissue infections [1]. It is generally a harmless commensal fungus that can turn into an opportunistic organism in immunocompromised or immunologically deficient individuals. Abnormal growth of $C$. albicans due to environmental imbalance such as the reduction of $\mathrm{pH}$ may result in candidiasis [2]. Different morphologies of $C$. albicans undergo certain interactions with host cells during an infection. It was suggested that epithelial mechanisms drive mucosal tissues to dissociate the pathogenic and commensal states of $C$. albicans [3]. For example, $C$. albicans cells treated with a medicinal plant extract showed a declined adhesion to surfaces, thereby inhibiting virulence factors of C. albicans [4]. The primary factor in the fungal colonization of human tissues is adherence to host surfaces; this process is controlled and induced by several cell signaling cascades in both the fungus and the environment. Also, Candida can adhere to the surfaces of medical devices and form biofilms [5].

The difficulty to eradicate Candida infections is owing to its unique switch between yeast and hyphae forms and more likely to biofilm formations that render resistance to antifungal therapy.

Plants are known sources of natural medicines [6]. Medicinal plants possess therapeutic properties and beneficial pharmacological effects on the body. A certain plant can be declared as medicinal when one or more of its organs contain a necessary substance that can be used for therapeutic purposes or used as a precursor for the synthesis of useful drugs [7].

Plants synthesize hundreds of chemical compounds for functions that include defense against insects, fungi, diseases, and herbivorous mammals. Since a single plant contains widely diverse phytochemicals, the effects of using a whole plant as medicine are uncertain. Further, the phytochemical content and pharmacological actions, if any, of many plants having medicinal potential remain unassessed by rigorous scientific research to define efficacy and safety [7].

Therefore, this study investigates the effects of gallic acid and vasicin as anti-adhesions against $C$. albicans adhesion during epithelial cell infection of vagina.

\section{Materials and methods}

\section{Samples Collection and Fungal isolation}

Vaginal swabs were collected from women referred to Al-Yarmouk Hospital, Alwiyah Hospital and Gynecological Private Clinic in Baghdad, Iraq, during the period extended from September to 
December 2018. The samples were collected in sterile swabs containing $5 \mathrm{ml}$ of normal saline from women patients with vaginal discharge after being subjected to CLS for diagnosis. All samples were cultured on Sabouraud Dextrose agar (SDA) as slants, tightly wrapped with parafilm and stored at $4{ }^{\circ} \mathrm{C}$ [8].

\section{Identification of candida isolates}

The isolates were identified as $C$. albicans depending on the microscopic morphology, morphological features on culture media, and VITEK 2 System.

\section{Plant extracts}

Vasicine alkaloid was isolated from the concentrated leaves extract of $A$.vasica by the acid-base method [9], while Gallic acid was isolated from Punica granatum L. using ethyl acetate (organic solvent) by a separator funnel [10].

\section{Characterization of plant extracts}

Vasicine alkaloid was characterized by the melting point of the partially purified sample according an earlier study [11]. The chemical characteristics were investigated using the modified Dragendroff's reagent and high performance liquid chromatography (HPLC), as previously described [12]. Gallic acid was characterized by phytochemical screening, using few drops of ferric chloride solution with change in color indicating to the presence of phenols, while HPLC was also used for the same purpose [13],

\section{Determination of MIC Concentration for active plant compounds and antifungal drugs}

The MIC of the plant active materials (vasicin and gallic acid) and fluconazole drug was determined by the agar dilution technique. The test was used to ensure that the highest concentration of these compounds that did not seem to have a fungicidal effect against $C$. albicans growth, by mixing with Muller Hinton agar and incubation for $24 \mathrm{~h}$ at $37^{\circ} \mathrm{C}$ [14].

\section{Preparation of $C$. albicans suspension}

Ten milliliters of Sabouraud Dextrose broth medium was inoculated with $C$. albicans growth culture and incubated at $37^{\circ} \mathrm{C}$ for 24 hours. The yeast culture was washed twice with Phosphate Buffer Saline (PBS) concentrated by centrifugation at $1000 \mathrm{rpm}$ for $20 \mathrm{~min}$, and re-suspended in PBS [15, 16].

\section{Preparation of epithelial cells}

Uroepithelial cells were isolated from the urine of some healthy females from September 2018 until December 2019 by centrifugation at $6000 \mathrm{rpm}$ for $5 \mathrm{~min}$, then washed three times with PBS and recentrifuged at $6000 \mathrm{rpm}$ for $10 \mathrm{~min}$ before re-suspension in PBS [14].

\section{Fixative solution}

The fixative was prepared by mixing $30 \mathrm{ml}$ of methanol (99.8\%) with $10 \mathrm{ml}$ of acetic acid (99.8\%). It was used for the fixation of yeast and uroepithelial cells during staining by methylene blue [17].

\section{Candida adhesion test}

The adhesion test was achieved as follows [18]:

- A mixture of $0.1 \mathrm{ml}$ of the yeast suspension, $0.1 \mathrm{ml}$ of the epithelial cells suspension and 0.05 of PBS were incubated at $37^{\circ} \mathrm{C}$ for $2 \mathrm{hrs}$.

- Unattached yeast cells to uroepithelial cells were removed by centrifugation in PBS at $6000 \mathrm{rpm}$ for $10 \mathrm{~min}$.

- The pellet was re-suspended in PBS. A drop of the suspension was put on a microscopic slide, airdried, fixed with methanol: acetic acid (3:1) and stained with methylene blue.

-The adhered yeast cells to epithelial cells were observed by the compound light microscope.

- The control contained only epithelial cells.

\section{Anti-adhesion test using Vasicin, Gallic acid and Fluconazole}

After the activation of Candida for 24 hours, 500 microliters of the activated inoculum was taken and concentrated using centrifuge at $6000 \mathrm{rpm}$ for $5 \mathrm{~min}$, then $50 \mu \mathrm{l}$ of PBS was added and mixed with 500 microliters of epithelial cells [18]. After completing this step, the experience was divided into two lines:

In the first line, the mixture from the previous step was incubated at $37^{\circ} \mathrm{C}$ for 2 hours, then 50 microliters of the vasicin extract was added with different concentrations (200, 400, 600, $800,1000,1200,1400,1600,1800$ and $2000 \mu \mathrm{g} / \mathrm{ml})$ and $(1,2,4,8,16,32,64,128,256$ and $516 \mathrm{mg} / \mathrm{ml})$, and stained for examination under light microscope. In the second line, 50 microliters of the vasicin extract with different concentrations $(200,400,600,800,1000,1200,1400,1600,1800$ and 2000 
$\mu \mathrm{g} / \mathrm{ml})$ and $(1,2,4,8,16,32,64,128,256$ and $516 \mathrm{mg} / \mathrm{ml})$ were added to the mixture. The samples were then incubated at $37^{\circ} \mathrm{C}$ for 2 hours, stained, and examination under a light microscope. As for gallic acid extract, the previous experiment repeated with various concentrations $(200,400,600,800$, $1000,1200,1400,1600,1800,2000 \mu \mathrm{g} / \mathrm{ml})$. Fluconazole antifungal drug is commonly used to treat vaginal yeast infections caused by Candida. This antifungal drug was treated in the same way as the vasicin and gallic acid extracts in the previous experiments, with different concentrations (200, $400,600,800,1000,1200,1400,1600,1800,2000 \mu \mathrm{g} / \mathrm{ml})$.

\section{Results and discussion}

\section{Isolation and Identification}

One hundred samples of high vaginal swabs [HVS] were collected from women with symptoms of vaginal infection who visited Gynecological private clinics and educational hospitals (Al-Yarmouk and Al-Alwiya). The collection was performed between September and December 2018. Half of the samples was collected from pregnant whereas the other half was from non-pregnant women. Samples were tested by microscopic examination and culture on SDA.

Colonial morphology, gram staining, and VITEK2 test were carried out for the identification of the isolated organisms. Thirty samples showed positive results of Candida albicans.

The characterization of the samples of vaginal discharge showed that $30(30 \%)$ of infections were caused by Fungi (100\% were Candida albicans), 47 by Gram negative bacteria, and 23 by Gram positive bacteria.

These results approximately agree with those reported by other authors [19], who showed that Candida albicans was detected in $20 \%$ of the subject samples. Onyia revealed that about $90 \%$ of this infection is caused by Candida albicans and $10 \%$ by other species of Candida [20]. This infection has been reported as the common cause of vaginitis, second to bacterial vaginosis and, generally, the infections occur when there is an imbalance in the $\mathrm{pH}$ of the vagina [21].

The over-growth of this fungus in the vagina leads to a burning sensation in the vaginal vulva, the production of heavy white/yellow curd-like discharge and/or an itchy vulva, pruritus, dyspareunia, dysuria, irritation, soreness of the vulva and other discomforting symptoms that will ensure frequent hospital visits [20]. The present results showed that $C$. albicans infections were more in pregnant (21 cases) than non- pregnant women (9 cases), which agrees with the results reported earlier [22].

\section{Determination of MIC for active plant compounds and antifungal drug}

The effects of the active compounds of plant extracts and the antifungal drug against $C$. albicans were tested by using MIC with four dilutions which showed resistance to fluconazole. The results are shown in Tables- 1 and 2. The MIC assays showed that the plant extracts and the antifungal drug do not appear to have fungicidal effects on the isolates of $C$. albicans tested at these concentrations.

Table 1- Minimum inhibitor concentration (MIC) of active compound of plant extract against $C$. albicans.

\begin{tabular}{|c|c|c|c|c|c|}
\hline \multirow{2}{*}{\begin{tabular}{c} 
Plant extract \\
\cline { 1 - 5 }
\end{tabular}} & CA. 2 & CA. 8 & CA. 20 & $\begin{array}{c}\text { Stock of } \\
\text { plant } \\
\text { extract }\end{array}$ \\
\hline \multirow{3}{*}{ MIC } & Vasicin $(\mathrm{mg} / \mathrm{ml})$ & $>516 \mathrm{mg} / \mathrm{ml}$ & $>516 \mathrm{mg} / \mathrm{ml}$ & $>516 \mathrm{mg} / \mathrm{ml}$ & $516 \mathrm{mg} / \mathrm{ml}$ \\
\cline { 2 - 6 } & Vasicin $(\mu \mathrm{g} / \mathrm{ml})$ & $>2000 \mu \mathrm{g} / \mathrm{ml}$ & $>2000 \mu \mathrm{g} / \mathrm{ml}$ & $>2000 \mu \mathrm{g} / \mathrm{ml}$ & $2000 \mu \mathrm{g} / \mathrm{ml}$ \\
\cline { 2 - 6 } & Gallic acid $(\mu \mathrm{g} / \mathrm{ml})$ & $>2000 \mu \mathrm{g} / \mathrm{ml}$ & $>2000 \mu \mathrm{g} / \mathrm{ml}$ & $>2000 \mu \mathrm{g} / \mathrm{ml}$ & $2000 \mu \mathrm{g} / \mathrm{ml}$ \\
\hline
\end{tabular}

Table 2- Minimum inhibitor concentration (MIC) of the antifungal drug (Fluconazole) against $C$. albicans.

\begin{tabular}{|c|c|c|c|c|c|}
\hline & $\begin{array}{c}\text { C.albicans } \\
\text { Fluconazole }\end{array}$ & CA. 2 & CA. 8 & CA. 20 & $\begin{array}{c}\text { Stock of } \\
\text { Fluconazole }\end{array}$ \\
\hline MIC & Fluconazole $(\mu \mathrm{g} / \mathrm{ml})$ & $>2000 \mu \mathrm{g} / \mathrm{ml}$ & $>2000 \mu \mathrm{g} / \mathrm{ml}$ & $>2000 \mu \mathrm{g} / \mathrm{ml}$ & $2000 \mu \mathrm{g} / \mathrm{ml}$ \\
\hline
\end{tabular}

Fluconazole is widely used clinically for treating pathogenic fungal infections, specifically those caused by $C$. albicans [23]. Recently, studies from many countries have shown an increased prevalence of fluconazole-resistant strains of $C$. albicans [24]. 
The antibacterial as well as antifungal activities of any plant depend on the extraction conditions, such as type and concentration of the solvent and time and temperature for the extraction process. All these factors affect the type and the amount of the active material that is extracted [25]. The mode of action of these compounds, such as polyphenols, is generally attributed to polyphenol-protein interactions, although different mechanisms have been suggested, including inhibition of microbial enzymes, actions on membranes, or deprivation of substrates required for microbial growth [26].

They have many roles in eukaryotic membranes, including establishing membrane fluidity, regulating membrane-bound enzymes and maintaining membrane permeability. Ergosterol is found in fungal cell membranes, and the lack of detectable ergosterol in fungal cell membranes after gallic Acid treatment suggests damage to the sterol biosynthetic pathway and subsequent reduction in the viability of C. albicans [27, 28].

Phenolic compounds (e.g. gallic acid), initially affect cell membrane, changing permeability and causing the leakage of cellular content, or interfere with membrane proteins resulting in structure disrupting . In addition, they disrupt cell wall and cell membrane synthesis [29]. Polyphenols may affect the bacterial cell wall, inhibit enzymes by oxidized agents, interact with proteins and disturb the co-aggregation of microorganisms [30]. Pomegranate extracts were reported to have broad bioactivities including antimicrobial, anti-inflammatory and antitumor effects, and have been used in traditional Uyghur medicine for many years [31].

\section{Effects of the plants active compounds and antifungal drug on adhesion activity}

The ability of $C$. albicans isolates to adhere to the epithelial cells was detected by calculations of the number of adherent $C$. albicans cells under the light microscope.

Forty cells of $C$. albicans adhered to the assayed epithelial cells. These data are regarded as a control for the detection of the effects of the MIC of plants active compounds and the antifungal drug on the adhesion ability of $C$. albicans (Figure-1).

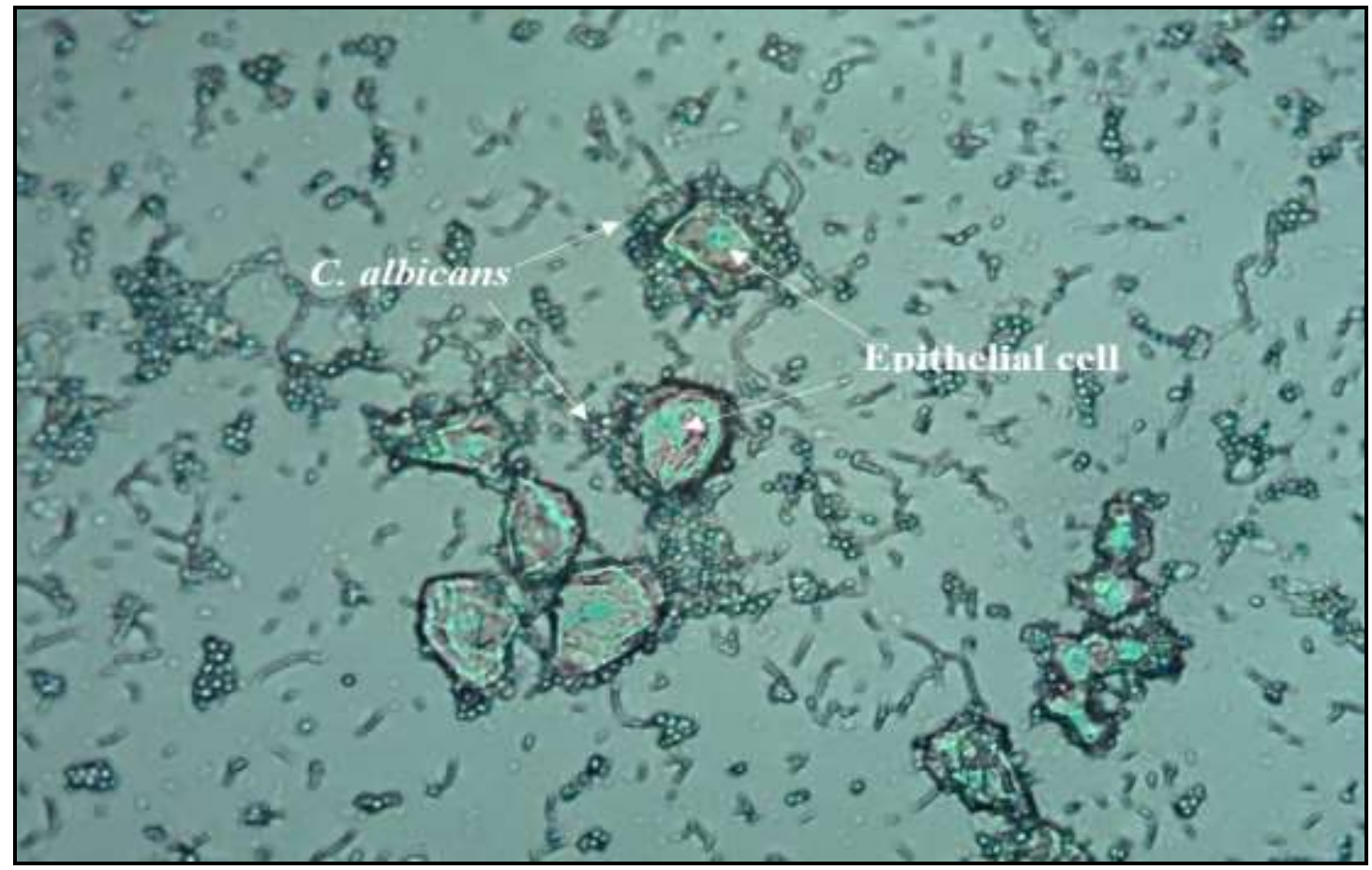

Figure 1- The adhesion of C. albicans isolates on epithelial cells.

\section{Effect of vasicin on adhesion activity of $C$. albicans}

No $C$. albicans cells were adhered to epithelial cells before and after the incubation with vasicin with concentrations of $128-516 \mathrm{mg} / \mathrm{ml}$. Also, at treatment with $64 \mathrm{mg} / \mathrm{ml}$ of vasicin, no C. albicans cells were adhered, but before incubation at the same concentration, four cells of $C$. albicans were found adhered on epithelial cells. The other concentration showed a variable number of $C$. albicans adhered to epithelial cells, in contrast to the control $(C$. albicans without the extracts or antifungal drug), as shown in Figure-2. 
As shown in Figure-3, no $C$. albicans cells were adhered to epithelial cells, only when vasicin was added with a concentration of $1800-2000 \mu \mathrm{g} / \mathrm{ml}$. The other concentrations showed a variable number of $C$. albicans adhered to the epithelial cells.

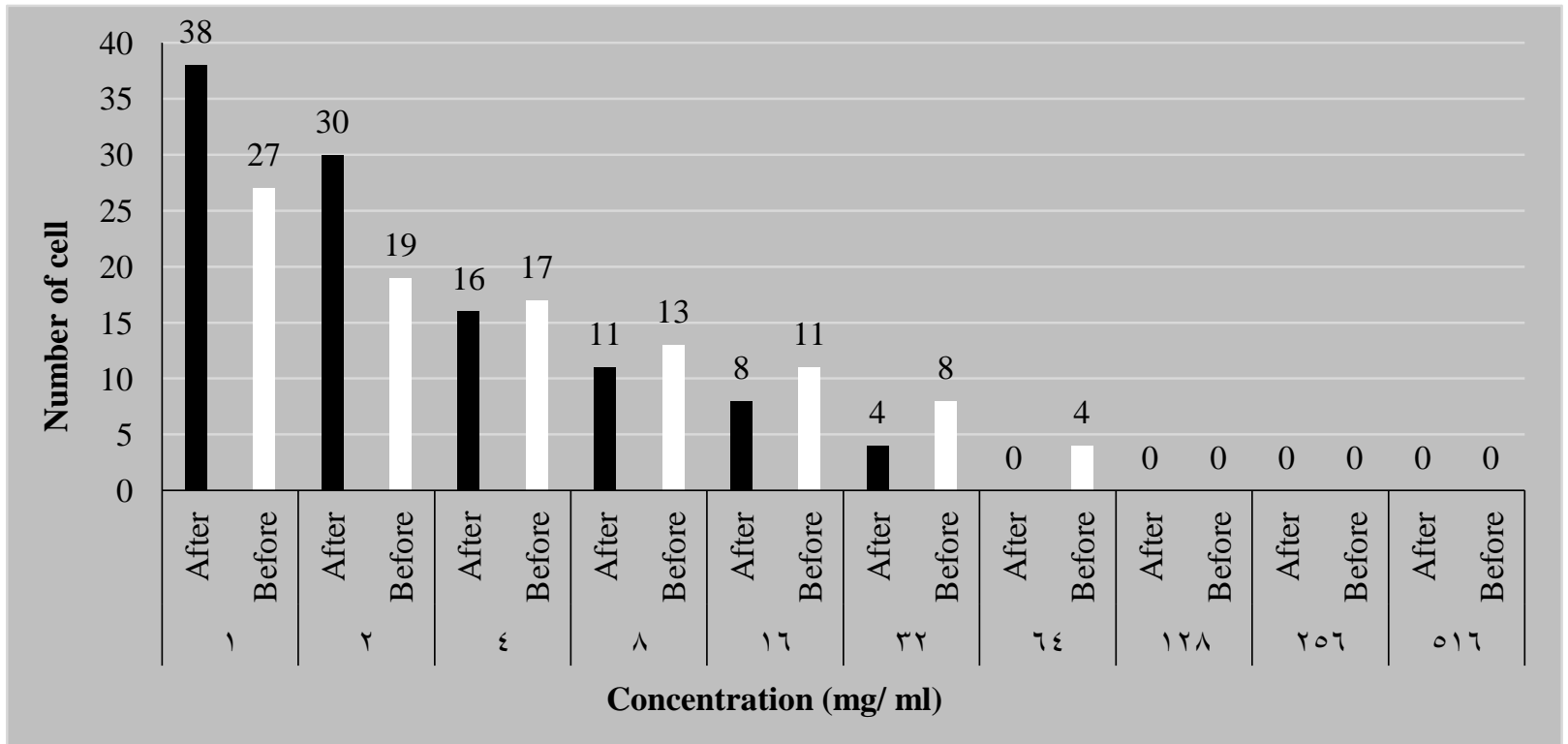

Figure 2- Anti-adhesion activity of Vasicin $(\mathrm{mg} / \mathrm{ml})$ against $C$. albicans.

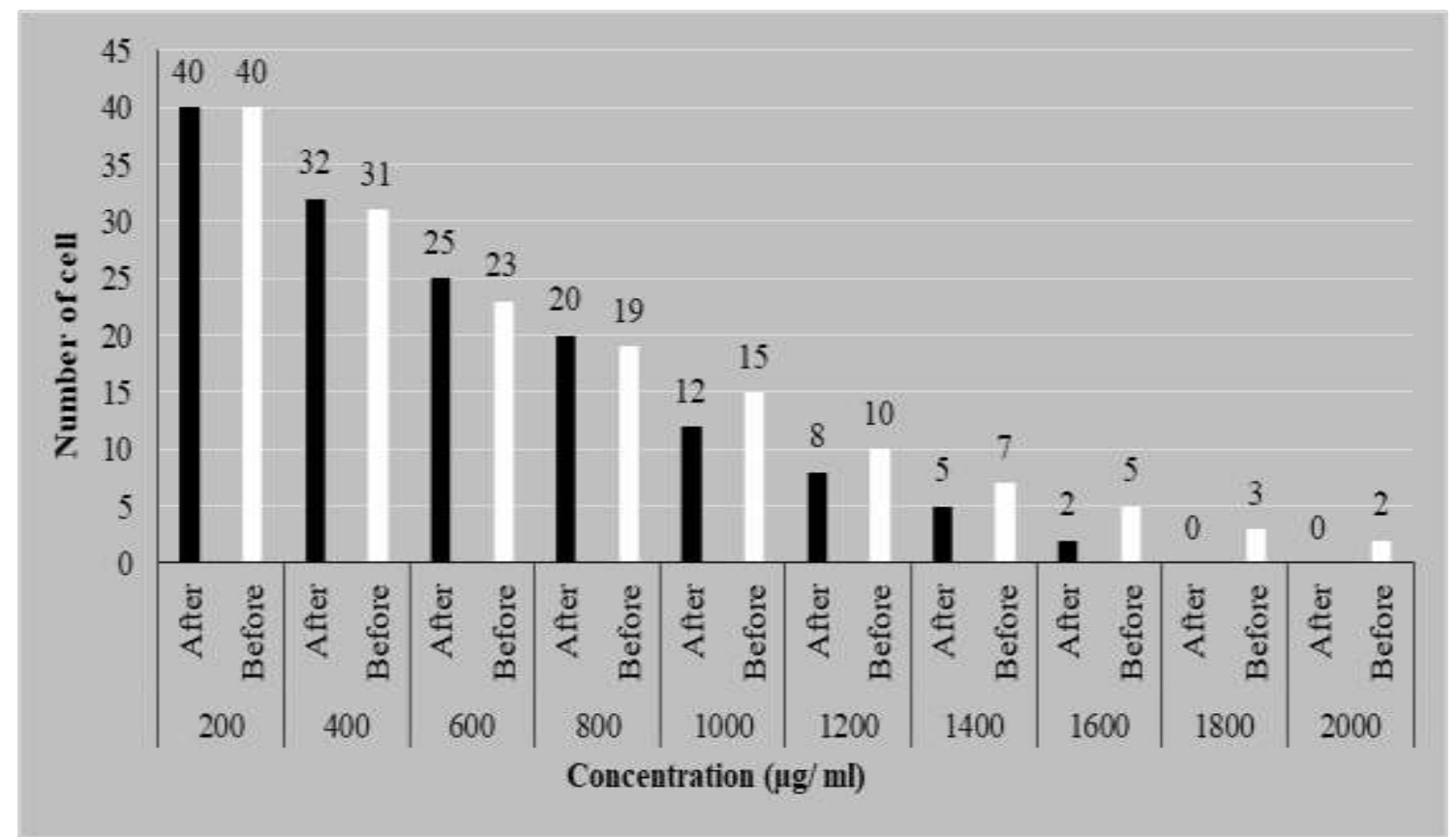

Figure 3- Anti-adhesion activity of Vasicin ( $\mu \mathrm{g} / \mathrm{ml})$ against $C$. albicans.

The activity of vasicin concentration in the $\mathrm{mg} / \mathrm{ml}$ was higher than that in $\mu \mathrm{g} / \mathrm{ml}$, which showed less number of $C$. albicans adhered on epithelial cells.

\section{Effects of Gallic Acid on the adhesion activity of $C$. albicans}

$C$. albicans showed no adhered cells to epithelial cells when gallic acid was added with concentrations of $1800-2000 \mu \mathrm{g} / \mathrm{ml}$. Only the concentration of $2000 \mu \mathrm{g} / \mathrm{ml}$ of gallic acid showed no adhered cells before incubation in the suspension. The other concentrations showed a variable number of $C$. albicans adhesion to epithelial cells in contrast to the control (C. albicans without the extracts), as shown in Figure-4. 


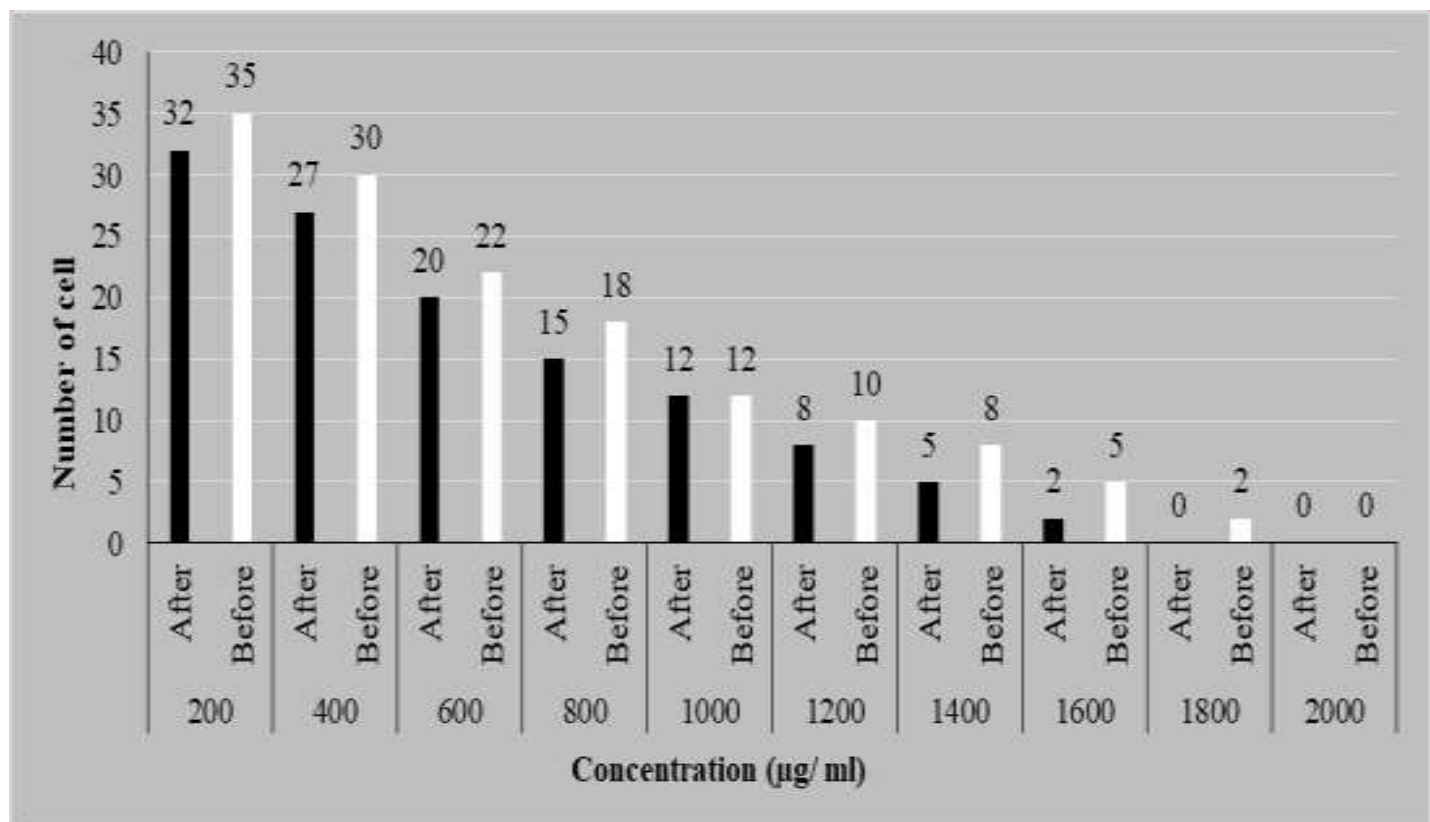

Figure 4- Anti-adhesion activity of Gallic Acid ( $\mu \mathrm{g} / \mathrm{ml})$ against C. albicans.

Vasicin and gallic acid activities when used the concentrations of $\mu \mathrm{g} / \mathrm{ml}$ showed approximately equal effects on the number of $C$. albicans adhesion on epithelial cells. The radiolabeled adhesion and the CFU counting assays suggested that vasicin and gallic acid have anti-adhesive effects.

Plant extracts and surfactants were evaluated for their anti-candidal-adhesive properties both on epithelial cells and on inert surfaces by some researchers [32]. Patel et al. showed that Dodonaea viscosa var. angustifolia (Sand Olive plant) crude extract could inhibit the adhesion of C. albicans isolated from HIV-seropositive and HIV-seronegative individuals to oral epithelial cells [33]. The date extract has also been proven to decrease the adhesion of three different species of candida to epithelial cells [40]. Previous studies have been carried out using various substances to assess their effect on $C$. albicans adhesion, for example, some plant extracts and surfactants, including bio-surfactants, etc. [34]. A recent study in Iraq detected the effects of the MIC of pomegranate peel extracts on the adhesion ability of bacteria and showed a clear decline in the adhesion activity when the bacteria was treated with peel extracts [35].

The relation between candidal adherence to host epithelial cells or acrylic denture surfaces and the ability of Candida to colonize and cause disease has been investigated in a number of studies. Colonization of the oral cavity is facilitated by several specific (receptor-ligand) and non-specific (electrostatic and electrodynamic) interactions between Candida and oral surfaces [36]. The adhesion process of Candida is complex and involves biological and non-biological factors. The adhesion capacity of Candida seems to influence its infection and colonization potential. Adhesion is not only affected by yeast conditions; variations in the epithelial surface also have a critical role in the adhesion phenomenon [37].

Cell surface hydrophobicity, which contributes to the interaction between the cells and the surfaces, seems to be an important factor in the adhesion of $C$. albicans. There are statistically significant correlations between cell hydrophobicity and the adhesion of $C$. albicans to the epithelial cells of the mouth and acrylic resin surfaces. The hydrophobic nature of $C$. albicans' cell surface is thought to be associated with the adherence of the yeast to epithelial cells and plastic devices. A correlation between the hydrophobicity of $C$. albicans and its adherence to HeLa cells has been reported. Polyenes bind avidly to ergosterol in fungal membranes, forming channels that allow $\mathrm{K}^{+}$and $\mathrm{Mg}^{2+}$ to leak out of the cell. The limited exposure of oral $C$. albicans isolates to polyenes reduces the relative cell surface hydrophobicity and candidal adherence to epithelial cells [38]. The adhesion occurs because $C$. albicans forms the fibrous layer composed of multiple sugars on the surfaces of cells during the stationary phase of growth [39].

Receptor analogs, adhesion analogs, and surface-modifying agents were used to inhibit the adhesion of microbes onto host cells. The number of organisms developing resistance to antiadhesive 
substances seems to be less compared with antimicrobial agents. However, the limitation of this kind of therapy is the requirement of multiple anti-adhesion agents to counter each type of adhesion of infecting pathogens [40].

The effect of the plant extracts is attributed to their ability to inhibit cell attachment. The cell attachment is the initial stage in biofilm formation following surface conditioning which creates a favorable environment for bacterial attachment. Surface conditioning is achieved by the adsorption of substances that include nutrients, organic, and inorganic molecules that are important for the growth of the cells, which in turn promotes cell adhesion and biofilm formation. Therefore, it can be postulated that pretreatment of the surface with plant extracts produces an unfavorable film that promotes detachment, thereby reducing the surface adhesion [41]. Janecki and Kolodziej explained the activity of plants active compounds that could be used as anti-adhesive agents against pathogenic microbes and showed capabilities of these compounds of interacting with macromolecules, including carbohydrates and proteins, which made these compounds as promising anti-adhesive and anti-biofilm agents [26]. The success of plant extracts in inhibiting cell attachment and reducing microbial colonization on surfaces of epithelial mucosa, which lead to infection, represented the important steps that achieved the growth of an already established biofilm [41].

\section{Effects of Fluconazole on adhesion activity of $C$. albicans}

C. albicans showed no cells to be adhered to epithelial cells when fluconazole was added with concentrations of $1000-2000 \mu \mathrm{g} / \mathrm{ml}$. Only a concentration of $2000 \mu \mathrm{g} / \mathrm{ml}$ of fluconazole showed no adhered cells before incubation with the suspension. The other concentration demonstrated a variable number of $C$. albicans adhered to epithelial cells, in contrast to the control $(C$. albicans without the extracts), as shown in Figure-5.

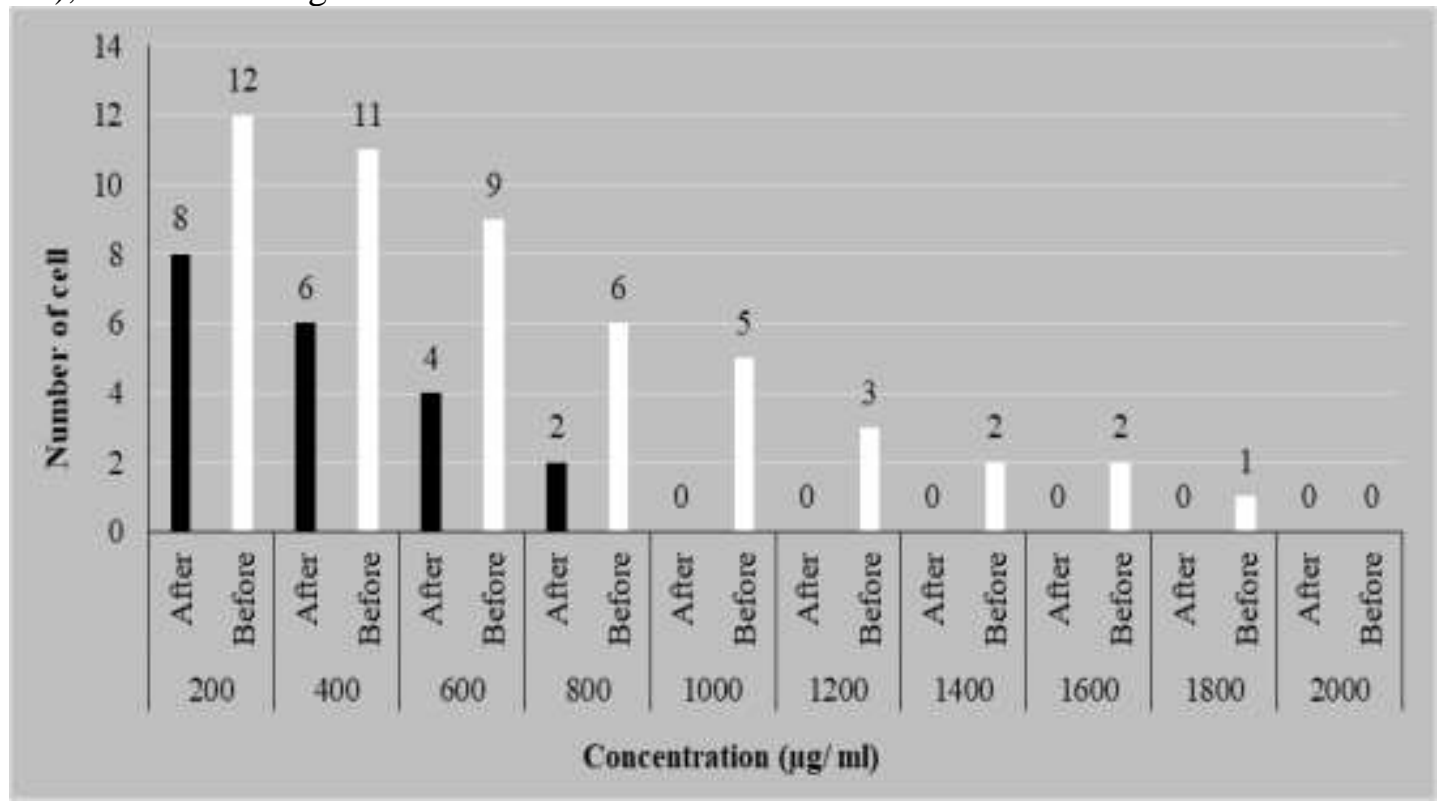

Figure 5- Anti-adhesion activity of Fluconazole $(\mu \mathrm{g} / \mathrm{ml})$ against $C$. albicans.

Vasicin and gallic acid activities in the $\mu \mathrm{g} / \mathrm{ml}$ concentration showed less effects on the number of C. albicans adhered on the epithelial cells than that of fluconazole, which showed more than the half of the number of $C$. albicans adhered on epithelial cells when added to the suspension.

A previous study showed that cells pre-treated with fluconazole had a reduction in the adhesion of C. albicans cells to the epithelial cells, which ranged from 0 to $72.9 \%$, [42]. Also, another study used low doses of fluconazole and showed a reduction in the adhesion of C. albicans [43].

Another study found that incubation of HeLa cells with Candida spp., in the presence of amphotericin $\mathrm{B}$, nystatin or natamycin, reduced the candidal adherence to these cells. When compared to amphotericin B, nystatin and natamycin suppressed adherence less effectively and these differences were statistically significant. The MIC and sublethal concentrations of nystatin reduced the adherence of $C$. albicans to cell monolayers by 35 and $47 \%$, respectively. Interestingly, following the "limited exposure prior to adhesion" procedure, nystatin reduced the adherence of $C$. albicans to the epithelial cells by 54 and $73 \%$ at the MIC and sublethal concentration, respectively [15]. 
The effects of antifungal drugs on candidal adhesion to epithelial cell has been examined following (i) pre-incubation of the isolates with the drug, (ii) pre-treatment of BECs with the drug, and (iii) limited exposure $(1 \mathrm{~h})$ of the isolates to sub lethal concentration of the drug, and subsequent removal of the drug. This study have indicated that pre-exposure of either the target cell surface or the yeasts to antifungal drugs results in reduced adhesion, which in vivo may enhance the effect of the topical agent [15].

\section{Conclusions}

From 100 samples of infections, $30 \%$ were caused by $C$. albicans. The maximum concentration used for vasicin $(516 \mathrm{mg} / \mathrm{ml}$ and $2000 \mu \mathrm{g} / \mathrm{ml})$, Gallic acid $(2000 \mu \mathrm{g} / \mathrm{ml})$ and Fluconazole $(2000 \mu \mathrm{g} / \mathrm{ml})$ did not seem to have a fungicidal effect on the isolates of $C$. albicans tested. Both the alkaloid (vasicine), the phenol (gallic acid) and fluconazole used in this study were able to show anti-adhesion activity in vitro. Vasicin and gallic acid activities exhibited approximately equal effects on the number of $C$. albicans adhered to epithelial cells, while fluconazole showed more effects on $C$. albicans adhesion.

\section{References}

1. Dadar, M., Tiwari, R., Karthik, K., Chakraborty, S., Shahali, Y. and Dhama, K. 2018. Candida albicans-Biology, molecular characterization, pathogenicity, and advances in diagnosis and control-An update. Microbial pathogenesis, 117: 128-138.

2. Pfaller, M. A. and Diekema, D. J. 2007. Epidemiology of invasive candidiasis: a persistent public health problem. Clinical microbiology reviews, 20(1): 133-163.

3. Rast, T. J., Kullas, A. L., Southern, P. J. and Davis, D. A. 2016. Human epithelial cells discriminate between commensal and pathogenic interactions with Candida albicans. PloS one, 11(4): $\mathrm{e} 0153165$.

4. Hmoteh, J., Musthafa, K. S., and Voravuthikunchai, S. P. 2018. Effects of Rhodomyrtus tomentosa extract on virulence factors of Candida albicans and human neutrophil function. Archives of oral biology, 87: 35-42.

5. Zordan R. and Cormack B. 2012. Adhesins on Opportunistic Fungal Pathogens. In: Calderone RA, Clancy CJ, ed. Candida and Candidiasis: ASM Press, Washington, DC, 243-259.

6. Soliman, S., Alnajdy, D., El-Keblawy, A. A., Mosa, K. A., Khoder, G. and Noreddin, A. M. 2017. Plants' natural products as alternative promising anti-Candida drugs. Pharmacognosy reviews, 11(22): 104.

7. Ahn, K. 2017. The worldwide trend of using botanical drugs and strategies for developing global drugs. BMB reports, 50(3): 111.

8. Vandepitte, J., Verhaegen, J., Engbaek, K., Rohner, P., Piot, P., Heuck, C. C., and Heuck, C. C. 2003. Basic laboratory procedures in clinical bacteriology. World Health Organization.

9. Ambi, A.A., Abdurrahman, E.M., Sule, M.I., Pateh, U.U., Abdurrahman, Y.R. and Ibrahim, N.D.G. 2007. Phytochemical screening and histopathological studies on the seeds of Colocynthis citrullus in albino rats. Nigerian J. of Pharmaceutical Scie. 6(2): 7-13.

10. Bhagat, S., Dongre, P., Bhagat, S., and Dikpati, A. 2015. Extraction and isolation of gallic acid from self-generated fermentation system of Terminalia chebula. Journal of Chemical and Pharmaceutical Research, 7(4): 170-174.

11. Harbone, J. B. 1984. Phytochemical methods: a guide to modern techniques of plant analysis .Chapman and Hall Co.New York, Third Edition 1.289.

12. Pandita, K., Bhatia, M. S., Thappa, R. K., Agarwal, S. G., Dhar, K. L., and Atal, C. K. 1983. Seasonal variation of alkaloids of Adhatoda vasica and detection of glycosides and N-oxides of vasicine and vasicinone. Planta medica, 48(06): 81-82.

13. Opara, L. U., Al-Ani, M. R., and Al-Shuaibi, Y. S. 2009. Physico-chemical properties, vitamin C content, and antimicrobial properties of pomegranate fruit (Punica granatum L.). Food and Bioprocess Technology, 2(3): 315-321.

14. Polaquini, S. R., Svidzinski, T. I., Kemmelmeier, C., and Gasparetto, A. 2006. Effect of aqueous extract from Neem (Azadirachta indica A. Juss) on hydrophobicity, biofilm formation and adhesion in composite resin by Candida albicans. Archives of oral biology, 51(6): 482-490. 
15. Dorocka-Bobkowska, B., Konopka, K. and Düzgüneş, N. 2003. Influence of antifungal polyenes on the adhesion of Candida albicans and Candida glabrata to human epithelial cells in vitro. Archives of oral biology, 48(12): 805-814.

16. Johann, S., Silva, D. L., Martins, C. V., Zani, C. L., Pizzolatti, M. G. and Resende, M. A. 2008. Inhibitory effect of extracts from Brazilian medicinal plants on the adhesion of Candida albicans to buccal epithelial cells. World Journal of Microbiology and Biotechnology, 24(11): 2459-2464.

17. Atlas, R.M.; Parks, L.C. and brown, A.E. 1995. Laboratory mannal of experimental microbiology. Mosby. Year book, InC. St. Louis. Baaltimor.

18. Pavithra, J. A., Srinikethan, G., Shubhada, C., Pradeep, K., Gopala, M., Kulkarni, R., and Praveenchandra, K. R. 2014. Effect of five plant extracts on adhesion of Candida albicans onto human buccal epithelial cells: an in-vitro study. Egyptian Pharmaceutical Journal, 13(2): 137.

19. Mbim, E. N., Mboto, C. I., George, U. E., Umego, C. F., Edet, U. O., and Orajiaka, N. A. 2017. Prevalence of vaginal candidiasis among female students of a hostel in the University of Calabar, Calabar. Journal of Applied Life Sciences International, 13(3):1-7.

20. Onyia, J. 2015. Prevalence of vulvovaginal candidiasis among nonpregnant women attending a tertiary health care facility in Abuja, Nigeria. Research and Reports in Tropical Medicine, 6:37-42.

21. Al-Ahmadey, Z. Z., and Mohamed, S. A. 2014. Vulvovaginal candidiasis: Agents and its virulence factors. Microbiology Research International, 2(3): 28-37.

22. Altayyar, I. A., Alsanosi, A. S., and Osman, N. A. 2016. Prevalence of vaginal candidiasis among pregnant women attending different gynecological clinic at South Libya. European Journal of Experimental Biology, 6(3): 25-29.

23. Gao M, Wang H, Zhu L. 2016. Quercetin assists fluconazole to inhibit biofilm formations of fluconazole-resistant Candida albicans in in vitro and in vivo antifungal managements of vulvovaginal candidiasis. Cell Physiol Biochem, 40: 727-742.

24. Nadagir SD, Chunchanur SK, Halesh LH, Yasmeen K, Chandrasekhar MR, Patil BS. 2008. Significance of isolation and drug susceptibility testing of non-Candida albicans species causing oropharyngeal candidiasis in HIV patients. Southeast Asian J Trop Med Public Health; 39: 492495.

25. Kadhim, Z.R. 2012. Extraction and purification of flavonoids from Camellia sinesis leaves and Punica granatum peels and determination of their antioxidant activity.M.Sc. Thesis. Karbala Univ.

26. Janecki, A. and Kolodziej, H. 2010. Anti-Adhesive Activities of Flavan-3-ols and Proanthocyanidins in the Interaction of Group A-Streptococci and Human Epithelial Cells. Molecules, 15: 7139-7152.

27. Richter RK, Mickus DE, Rychnovsky SD, Molinski TF. 2004. Differential modulation of the antifungal activity of amphotericin B by natural and ent-cholesterol. Bioorg Med Chem Lett, 14: $115-118$.

28. Li, Z. J., Liu, M., Dawuti, G., Dou, Q., Ma, Y., Liu, H. G., and Aibai, S. 2017. Antifungal activity of gallic acid in vitro and in vivo. Phytotherapy research, 31(7): 1039-1045.

29. Cushnie, T. T. and Lamb, A. J. 2011. Recent advances in understanding the antibacterial properties of flavonoids. International journal of antimicrobial agents, 38(2): 99-107.

30. Abdollahzadeh, S.; Mashouf, R.; Mortazavi, H.; Moghaddam, M.; Roozbahani, N. and Vahedi, M. 2011. Antibacterial and Antifungal Activities of Punica granatum Peel Extracts Against Oral Pathogens. J. of Dentistry. 8(1): 1-6.

31. Betanzos-Cabrera G, Montes-Rubio PY, Fabela-Illescas HE, Belefant-Miller H, Cancino-Diaz JC. 2015. Antibacterial activity of fresh pomegranate juice against clinical strains of Staphylococcus epidermidis. Food Nutr Res, 59: 27620.

32. Ma GZ, Wang CM, Li L, Ding N, Gao XL. 2015. Effect of pomegranate peel polyphenols on human prostate cancer PC-3 cells in vivo. Food Sci Biotechnol, 24: 1887-1892.

33. Mondello F, De Bernardis F, Girolamo A, Cassone A, Salvatore G. 2006.Invivo activity of terpinen-4-ol, the main bioactive component of Malaleuca alternifolia Cheel (tea tree) oil against azole susceptible and resistant human pathogenic Candida species. BMC Infect Dis, 6: 158.

34. Lyon JP, dos Santos FV, de Moraes PC, Moreira LM. 2011. Inhibition of virulence factors of Candida spp. by different surfactants. Mycopathologia, 171: 93-101. 
35. Patel M, Gulube Z, Dutton M. 2009. The effect of Dodonaea viscosa var. angustifolia on Candida albicans proteinase and phospholipase production and adherence to oral epithelial cells. $J$ Ethnopharmacol, 124: 562-565.

36. Abu-Elteen KH. 2000. Effects of date extract on adhesion of Candida species to human buccal epithelial cells in vitro. J Oral Pathol Med, 29: 200-205.

37. Janek, T., Łukaszewicz, M., and Krasowska, A. 2012. Antiadhesive activity of the biosurfactant pseudofactin II secreted by the Arctic bacterium Pseudomonas fluorescens BD5. BMC microbiology, 12(1): 24.

38. Hadi, B., S. 2013. Effect of some fruits peel extracts on the virulence of some pathogenic bacteria isolated from urinary tract infection in pregnant women in Karbala. M.Sc. Thesis. Karbala Univ.

39. AlSaidy, H. A. M. 2015. Diagnosis of some types of yeasts associated with the human body and treated in the Garlic and Colocynthis extracts. Eur J Agric For Res, 3: 1-14.

40. Ofek I, Hasty DL, Sharon N. 2003.Anti-adhesion therapy of bacterial diseases: prospects and problems. FEMS Immunol Med Microbiol, 38: 181-191.

41. Sandasi, M.; Leonard, C.M. and Viljoen, A.M. 2009. The in vitro antibiofilm activity of selected culinary herbs and medicinal plants against Listeria monocytogenes. J.compilation, 50 :30-35.

42. Gugnani, H. C., Becker, K., Fegeler, W., Basu, S., Chattopadhya, D., Baveja, U., and Murlidhar, A. 2003. Oropharyngeal carriage of Candida species in HIV-infected patients in India. Mycoses, 46(8): 281-288.

43. Egusa, H., Ellepola, A. N. B., Nikawa, H., Hamada, T. and Samaranayake, L. P. 2000. Exposure to subtherapeutic concentrations of polyene antifungals suppresses the adherence of Candida species to denture acrylic. Chemotherapy, 46(4): 267. 